\title{
Short communication: Chemical and sensory characteristics of Canestrato di Moliterno cheese manufactured in spring
}

\author{
A. Trani, G. Gambacorta, P. Loizzo, A. Cassone, and M. Faccia ${ }^{1}$ \\ Department of Soil, Plant, and Food Science, University of Bari, Via Amendola 165/A, 70126 Bari, Italy
}

\begin{abstract}
Canestrato di Moliterno is an Italian Protected Geographical Indication hard cheese, made in winter and spring from a mixture of ewe and goat milks, that has been poorly investigated. The present study was aimed at characterizing the cheese made in the warm season. Two series of samples, ripened in traditional rooms called fondaco as indicated in the official protocol of production, were taken from the main certified producers. The cheeses were analyzed for gross composition; proteolysis and lipolysis; volatile fraction; and organoleptic features. Gross composition was not completely homogeneous among the samples, but primary proteolysis and lipolysis were quite uniform. We observed variations in secondary proteolysis, likely caused by fluctuations in environmental conditions in the fondaco. The sensory profiles of the samples were homogeneous: the cheese was soluble, greasy, and adhesive, with a sheepfold and buttery odor. The main taste attributes were fermented, pungent, and bitter. Overall, the results of this study provide an initial contribution to the characterization of Canestrato di Moliterno, and could be used to improve marketing strategies.
\end{abstract}

Key words: Canestrato di Moliterno, proteolysis, lipolysis, sensory evaluation

\section{Short Communication}

Canestrato di Moliterno is an uncooked hard cheese obtained from a mixture of sheep milk (70-90\%) and goat milk (10-30\%), and it was recently acknowledged by the European Union as a Protected Geographical Indication (PGI) product. It is manufactured under artisanal conditions in the Basilicata region (southern Italy) from December to May. Its shape is cylindrical, and ripening time ranges from 2 mo (fresh type) to 12 mo (ripened type). The matrix is white but evolves to straw yellow with time, and it presents a compact structure with some small eyes. The flavor becomes

Received January 15, 2016.

Accepted April 12, 2016.

${ }^{1}$ Corresponding author: michele.faccia@uniba.it more or less piquant as ripening proceeds. The most characterizing points of production are (1) use of unpasteurized milk (raw, without addition of starter, or thermized, with the addition of autochthonous starter); (2) coagulation with paste rennet (lamb or kid); and (3) ripening in traditional rooms called fondaco (European Union, 2010). Fondaco are basement rooms that have walls at least $40 \mathrm{~cm}$ thick and 2 or more windows to allow moderate ventilation. In these rooms, temperature and relative humidity fluctuate in connection with external environmental conditions. Temperature fluctuation during the warm season is more marked than in winter and this, together with the seasonal variations of milk composition, causes differences in cheese quality: the cheese manufactured in spring contains less fat and presents a stronger taste and aroma (Istituto Nazionale di Sociologia Rurale, 1990; Pinarelli, 2006). Even though it is manufactured with a small percentage of goat milk, Canestrato di Moliterno has always been included in the family of Pecorino cheeses. Pecorino is a generic name that indicates Italian cheeses made from raw or thermized sheep's milk in the middle and south of Italy, according to ancient and unique manufacturing techniques (Cevoli et al., 2011; Tofalo et al., 2015). Several dozen varieties of this cheese type have been surveyed in Italy, and 11 are currently acknowledged as European Protected Designation of Origin (PDO) products (the "first-class" European quality label). Adequate information is available in the scientific literature about most important Pecorino cheeses, but information about Canestrato di Moliterno is very scarce, despite its PGI status (Rubino et al., 2009; Pirisi et al., 2011). The present paper is aimed at deepening our understanding of the chemical and biochemical traits, volatile fraction, and sensory characteristics of Canestrato di Moliterno made in the warm season.

Two sets of cheese samples, manufactured between March and May, were taken from 4 certified producers at $30 \mathrm{wk}$ of ripening. All producers performed vat thermization of the milk $\left(60^{\circ} \mathrm{C}\right.$ for $15 \mathrm{~min}$; Clerici, Cadorago, Italy), and used the same autochthonous starter (lyophilized lactic acid bacteria starter, developed and copyrighted by the Consorzio per la tutela del "Canestrato di Moliterno," Moliterno, Italy). Milk 
was coagulated at $38^{\circ} \mathrm{C}$ by adding lamb rennet paste to cause clotting within 10 to $15 \mathrm{~min}$. After coagulation, the coagulum was left to harden for about $30 \mathrm{~min}$, manually cut to a size of 3 to $4 \mathrm{~mm}$, stirred, and left to compact at the bottom of the vat. Then, the whey was drained off and the curd was cut into small blocks; the blocks were put into plastic molds that resemble ancient rush baskets (baskets are no longer used for hygienic reasons) and slightly pressed by hand. After brine-salting, the cheeses were stored in a primary ripening cellar $\left(12-14^{\circ} \mathrm{C} ; 75-80 \%\right.$ relative humidity) and, after $3 \mathrm{wk}$, transferred to the fondaco.

We performed the following chemical analyses: moisture, $\mathrm{NaCl}$, and pH (IDF, 1986, 1988, 1989); fat (Soxhlet method); total and water-soluble nitrogen (Kjeldahl method); and GC determination of total fatty acid composition (Faccia et al., 2015). Primary proteolysis was evaluated using urea PAGE (Andrews, 1983): the gel images were scanned, and the optical density of each casein band was expressed as the percent of total bands. Secondary proteolysis was assessed by determining the free amino acids in water-soluble nitrogen using the EZ:faast LC/MS amino acid analysis kit (Phenomenex, Torrance, CA). The liquid chromatography system employed was a rapid separation UltiMate 3000 coupled with a Velos Pro MS detector (Thermo Scientific Inc., Waltham, MA). The chromatographic conditions were column $=2.1$ (i.d.) $\times 250 \mathrm{~mm}$ (length), $5 \mu \mathrm{m}$ particle size, set at $30^{\circ} \mathrm{C}$; solvent $\mathrm{A}$, ammonium formiate 10 $\mathrm{m} M$ in water, solvent $\mathrm{B}$, ammonium formiate $10 \mathrm{~m} M$ in acetonitrile; gradient from 10 to $50 \%$ of solvent B in 20 min; capillary $320^{\circ} \mathrm{C}$, source heater $280^{\circ} \mathrm{C}$, sheath gas flow $241.3 \mathrm{kPa}$, auxiliary gas flow 8 (arbitrary units), full scan mode 100 to $600 \mathrm{Da}$, positive ionization. For quantitation, we added 3 internal standards (methionine $\mathrm{d} 3$, homoarginine, and homophenylalanine) to samples and standard solutions. We assessed lipolysis by GC determination of free fatty acids, extracted according to the method described by Lencioni et al. (1988) and analyzed as indicated for total fatty acids. We extracted the volatile compounds with solid-phase microextraction (SPME) and analyzed them using GC-MS as reported by Felicio et al. (2016), with some modifications. We weighed $1 \mathrm{~g}$ of grated cheese in an SPME glass vial and added 3-pentanone as an internal standard. The vial was equilibrated for $10 \mathrm{~min}$ at $50^{\circ} \mathrm{C}$, and then an SPME fiber (divinylbenzene/carboxen/ polydimethylsiloxane 50/30 $\mu \mathrm{m}$, Supelco, Bellefonte, PA) was exposed for $30 \mathrm{~min}$. For analysis, the fiber was inserted in the split injection port of a Trace 1300 gas chromatograph (Thermo Scientific Inc.) equipped with a TR-Wax-MS capillary column $20 \mathrm{~m} \times 0.1 \mathrm{~mm}$ i.d. $\times 0.1-\mu \mathrm{m}$ film thickness (Thermo Scientific Inc.). The thermal gradient used was as follows: $50^{\circ} \mathrm{C}$ for $0.1 \mathrm{~min}$; to $180^{\circ} \mathrm{C}$ at $13^{\circ} \mathrm{C} / \mathrm{min}$; finally, to $220^{\circ} \mathrm{C}$ at $18^{\circ} \mathrm{C} / \mathrm{min}$. We used the ISQ Single Quadrupole (Thermo Scientific Inc.) as the MS detector. We identified compounds using the National Institute of Standards and Technology database (NIST MS-Search; http://chemdata.nist.gov/ mass-spc/ms-search/), comparing with pure standards when possible and considering the Kovats retention time index.

Sensory evaluation was performed by a panel of 9 trained assessors (4 female and 5 male, aged 30-55 yr) who belonged to the staff of the Food Science and Technology section in our department. They were selected following international standards (ISO, 1993) and carried out a quantitative descriptive sensory analysis as reported by Scintu et al. (2010) and Gaze et al. (2015). The panel had 3 open training sessions on 3 commercial samples of different hard ewe cheeses. Panelists then evaluated the Canestrato di Moliterno samples in 2 sessions on different days (a 2-h session for each of the 2 sets of samples) and indicated a series of sensory descriptors. All descriptors were quantified on a 6-point scale and were selected based on weight percentage (frequency of citations $\times$ perceived intensity; AFNOR, 1994). Only descriptors with a weight percentage greater than $30 \%$ were considered.

All data were processed using SPSS version 19 (IBM, Armonk, NY). Discrete variables were described by their mode value and continuous variables by the mean. We compared producers for each continuous parameter using 1-way ANOVA, and we compared nonparametric variables using the Kruskal Wallis test.

The gross composition of the cheese samples was not fully homogeneous (Table 1). Except for protein and $\mathrm{pH}$, all parameters were significantly different among producers $(P<0.05)$. The fatty acid composition (Table 2) was uniform: the average ratio of saturated to unsaturated was 74:26, and CLA accounted for about $0.5 \%$ of total. This latter value was poor compared with those reported for ovine milk and cheese (Addis et al., 2005a; Nudda et al., 2005; Castro et al., 2009). However, it must be noted that the average CLA value was decreased by the very low concentrations detected in cheeses produced in late spring (May): the reduced availability of pasture may have been a cause. Lipolysis was uniform in the cheese samples (Table 2): the mean value of total free fatty acids was $7.21 \mathrm{~g} / \mathrm{kg}$ of cheese. This was an intermediate level of lipolysis (Collins et al., 2003) and lower than or comparable to those found in Romano and Fiore Sardo (Addis et al., 2005b; Pirisi et al., 2007). The most represented fatty acid was palmitic, followed by stearic and oleic acids. Short- and intermediate-chain fatty acids, which strongly contrib- 
Table 1. Mean values for $\mathrm{pH}$ and gross composition (\%) of 30-wk-old Canestrato di Moliterno cheese from different manufacturers (M1-M4)

\begin{tabular}{lcrrrc}
\hline Item & M1 & M2 & M3 & M4 & Total mean value \\
\hline pH & 5.31 & 5.35 & 5.34 & 5.33 & 5.33 \\
Moisture & 27.8 & 28.6 & 29.6 & 32.5 & $29.6^{*}$ \\
Fat & 36.9 & 35.7 & 36.3 & 34.0 & $35.7^{*}$ \\
Fat in DM & 51.1 & 50.0 & 47.3 & 50.3 & $49.7^{*}$ \\
Protein & 27.3 & 27.3 & 27.2 & 26.6 & 27.1 \\
Salt in moisture & 7.6 & 8.4 & 9.5 & 11.1 & $9.2^{*}$ \\
Ash & 7.8 & 8.1 & 6.9 & 7.0 & $7.5^{*}$ \\
\hline
\end{tabular}

*Different among producers at $P<0.05$.

ute to cheese flavor, accounted for about $26 \%$ of the total. Unlike many other Pecorino cheeses, butyric was not the most abundant free fatty acid.

As to primary proteolysis (Table 3), degradation of $\alpha_{\mathrm{S} 1}$-casein was almost complete in all samples, whereas $\beta$-casein was only partially hydrolyzed. On average, this latter fraction represented about $80 \%$ of total bands. The water-soluble nitrogen and ripening index (watersoluble $\mathrm{N} /$ total $\mathrm{N} \times 100$ ) was not statistically different among producers (mean values $9.5 \mathrm{~g} / \mathrm{kg}$ and $0.22 \%$ ). These results indicate that primary proteolysis was fairly homogeneous. The mean concentration of free amino acids had very high SD $(5.4 \mathrm{~g} / \mathrm{kg}$ of cheese \pm 1.65), suggesting that the rate of secondary proteolysis varied among producers. However, the free amino acid profile was uniform from a qualitative point of view (Figure 1): Glu was the most abundant AA, followed by Lys, Asn, Pro, Ile, and Val. Making a comparison with the proteolysis profile of Canestrato Pugliese, a PDO ewe cheese manufactured in a bordering geographical area using similar technology, we found that the ripening index was similar, as was the level and profile of free amino acids. However, the kinetics of degradation of the casein fractions differed: in Canestrato di Moliterno, hydrolysis of $\alpha_{\mathrm{S} 1}$-casein was faster, and that of $\beta$-casein was slower (Santoro and Faccia, 1998; Di Cagno et al., 2003). These differences could be linked to the lower concentration of $\mathrm{NaCl}$ and the absence of curd cooking in Canestrato di Moliterno, which should favor the activity of residual rennet, but could also be linked to the conditions of ripening. Measurements performed in a fondaco during the study revealed daily variations from 7 to $13^{\circ} \mathrm{C}$ in April, and from 13 to $20^{\circ} \mathrm{C}$ in July: such fluctuations can determine the rate of enzymatic activity.

We identified 59 volatile compounds by SPME-GC analysis (Table 4). Acids and ketones formed the main body of the profile, accounting for 67.20 and $17.41 \%$ of the total peak area, respectively. Alcohols, esters, and terpenoids were secondary compounds, accounting for $6.35,4.13$, and $3.57 \%$, respectively. The strong presence of acids confirmed findings from Collins et al. (2003),
Table 2. Mean values $(\mathrm{g} / \mathrm{kg})$ for total fatty acid and free fatty acids of 30-wk-old Canestrato di Moliterno

\begin{tabular}{|c|c|c|}
\hline Fatty acids & Mean \pm SD & Significance \\
\hline \multicolumn{3}{|l|}{ Total fatty acids } \\
\hline $\mathrm{C} 4$ & $14.55 \pm 5.12$ & $*$ \\
\hline C6 & $13.18 \pm 5.59$ & \\
\hline $\mathrm{C} 8$ & $10.46 \pm 4.25$ & \\
\hline $\mathrm{C} 10$ & $27.30 \pm 10.61$ & \\
\hline $\mathrm{C} 11$ & $0.23 \pm 0.14$ & $*$ \\
\hline $\mathrm{C} 12$ & $12.72 \pm 5.89$ & $*$ \\
\hline C14 & $32.11 \pm 11.28$ & \\
\hline C14:1 & $0.58 \pm 0.36$ & $*$ \\
\hline $\mathrm{C} 15$ & $3.25 \pm 0.53$ & \\
\hline $\mathrm{C} 16$ & $65.97 \pm 12.93$ & \\
\hline C16:1 & $3.15 \pm 1.00$ & \\
\hline $\mathrm{C} 17$ & $1.73 \pm 0.38$ & \\
\hline $\mathrm{C} 17: 1$ & $0.57 \pm 0.12$ & \\
\hline C18 & $28.09 \pm 8.65$ & \\
\hline C18:1 & $54.85 \pm 5.91$ & \\
\hline C18:2 & $6.58 \pm 0.93$ & \\
\hline C18:3 & $3.31 \pm 0.47$ & \\
\hline C18:2 cis- 9, trans- 11 & $1.11 \pm 0.15$ & \\
\hline C18:2 trans- 10, cis- 12 & $0.13 \pm 0.04$ & \\
\hline $\mathrm{C} 20$ & $0.84 \pm 0.30$ & \\
\hline $\mathrm{C} 21$ & $0.34 \pm 0.05$ & \\
\hline $\mathrm{C} 22$ & $0.27 \pm 0.14$ & $*$ \\
\hline C20:4n-6 & $0.32 \pm 0.02$ & \\
\hline Total & 281.64 & \\
\hline Total saturated & 211.04 & \\
\hline \multirow{2}{*}{\multicolumn{3}{|c|}{ Free fatty acids }} \\
\hline & & \\
\hline $\mathrm{C} 4$ & $0.55 \pm 0.11$ & \\
\hline C6 & $0.13 \pm 0.02$ & \\
\hline $\mathrm{C} 8$ & $0.19 \pm 0.07$ & $*$ \\
\hline $\mathrm{C} 10$ & $0.37 \pm 0.06$ & \\
\hline $\mathrm{C} 12$ & $0.22 \pm 0.03$ & \\
\hline $\mathrm{C} 14$ & $0.39 \pm 0.08$ & * \\
\hline $\mathrm{C} 16$ & $2.16 \pm 0.34$ & \\
\hline $\mathrm{C} 18$ & $1.61 \pm 0.31$ & * \\
\hline C18:1 & $1.15 \pm 0.50$ & $*$ \\
\hline C18:2 & $0.19 \pm 0.09$ & \\
\hline Total & 6.96 & \\
\hline Total saturated & 5.62 & \\
\hline Total unsaturated & 1.34 & \\
\hline
\end{tabular}

*Different among producers at $P<0.05$.

which considered these compounds to be primary contributors to the flavor of Italian hard cheeses. The most represented ketones were 2-nonanone and 2-heptanone, although the latter showed significant variation among producers. Besides having a common fruity flavor, 2-nonanone presents tea-like/medicinal/sour notes, whereas 2-heptanone is associated with a blue cheese/ mushroom flavor (Qian and Burbank, 2007). The profile of alcohols was similar in all samples, and both primary and secondary alcohols were detected. The most represented was 2-heptanol: it has an herbaceous/mushroom odor with a very low perception threshold (Qian and Burbank, 2007). Ethyl hexanoate, hexyl acetate, butyl butanoate, and butyl acetate were the main esters represented. The fruity attributes they are associated with varied from banana to green apple and ethereal/ 
Table 3. Casein fractions (\% of total casein) in 30-wk-old Canestrato di Moliterno cheese from different manufacturers (M1-M4)

\begin{tabular}{lrrrrrr}
\hline Casein fraction & M1 & M2 & M3 & M4 & Total mean value & Reference sample $^{1}$ \\
\hline$\alpha_{\mathrm{S} 1}-\mathrm{CN}$ & 0 & 1 & 3 & 4 & 2 & 37 \\
$\beta$-CN & 83 & 82 & 79 & 81 & 81 & 49 \\
$\gamma_{-} \mathrm{CN}$ & 17 & 15 & 13 & 12 & 14 & 9 \\
$\alpha_{\mathrm{S} 1}-\mathrm{I}-\mathrm{CN}$ & 0 & 2 & 5 & 3 & 3 & 5 \\
\hline
\end{tabular}

${ }^{1}$ 14-d-old Canestrato di Moliterno.

solvent (Qian and Burbank, 2007). Finally, the group of terpenoids contained D-limonene and $p$-menth-2-ene as major compounds, and $\alpha$-myrcene and $\alpha$-phellandrene as minor compounds. Terpenoids are responsible for herbaceous and flower odors, and have been proposed as molecular markers of milk (and cheese) from highland pastures. D-Limonene is commonly found in Italian and Spanish ewe's cheeses (Fernández-García et al., 2002; Di Cagno et al., 2003), whereas p-menth-2-ene has not been frequently reported in the literature.
Seventeen descriptive terms were selected for the sensory characterization of the cheese; 13 were homogeneously perceived in the samples, and 4 (salty, crystals, moldy, sour) received scores that differed significantly among producers (Table 5). The perception of crystals is given by the presence of small hard grains in the cheese matrix; it is called "seaminess" and is normally observed in ripened hard cheeses, such as Parmigiano Reggiano and Cheddar. It is caused by crystallization of poorly soluble compounds such as calcium lactate,

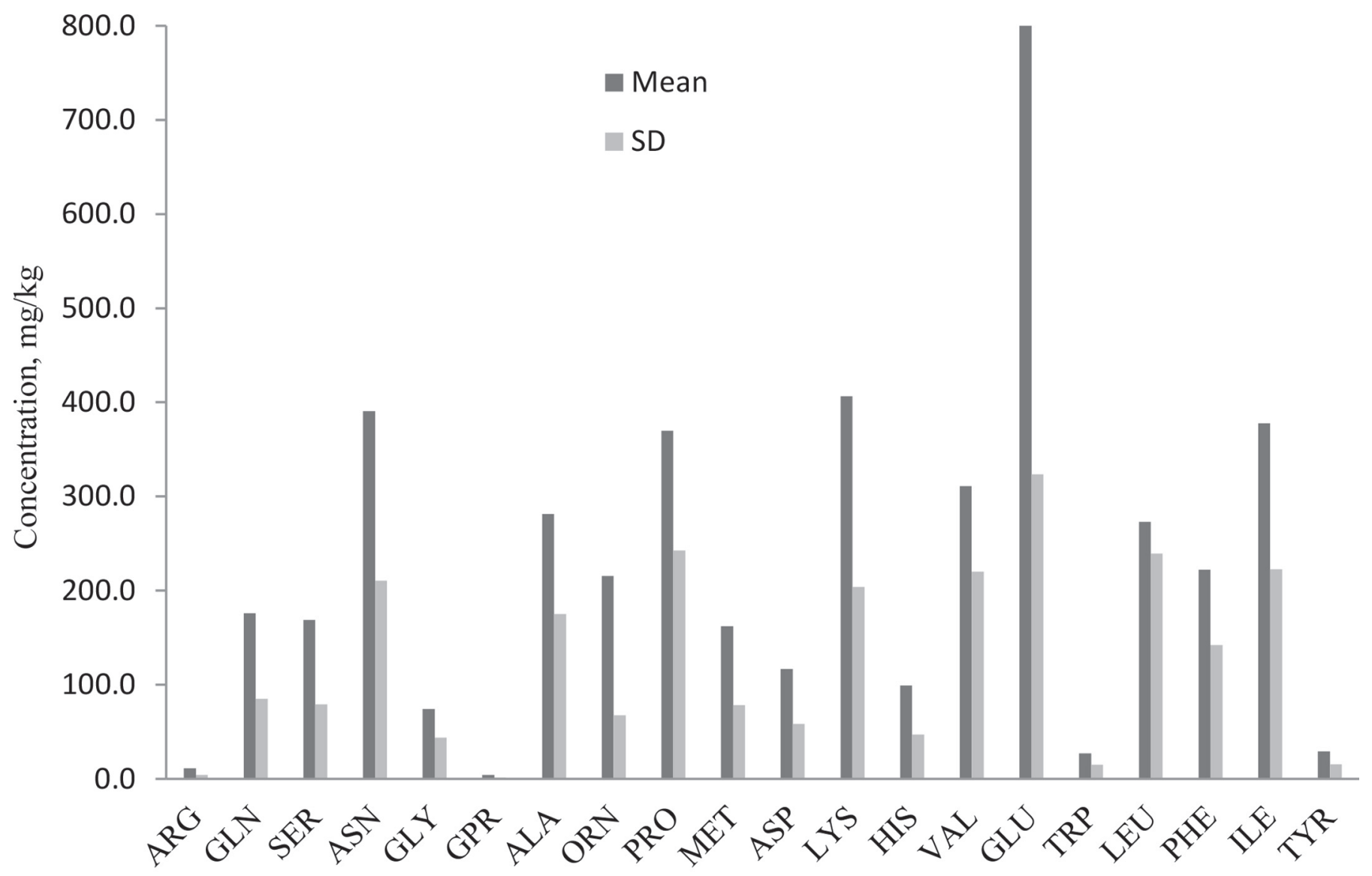

Amino Acid

Figure 1. Free amino acids profile of 30-wk-old Canestrato di Moliterno ( $\mathrm{mg} / \mathrm{kg}$ of cheese $\pm \mathrm{SD})$. 
Table 4. Volatile components $(\mathrm{mg} / \mathrm{kg}$ of cheese) identified in $30-\mathrm{wk}-$ old Canestrato di Moliterno cheese

\begin{tabular}{|c|c|c|c|}
\hline Volatile & $\begin{array}{l}\text { Retention time } \\
\quad(\min )\end{array}$ & Mean \pm SD & Significance \\
\hline Acetic acid & 6.46 & $7.30 \pm 0.36$ & \\
\hline Propionic acid & 7.30 & $0.22 \pm 0.03$ & \\
\hline Isobutyric acid & 7.56 & $0.14 \pm 0.01$ & \\
\hline Butanoic acid & 8.10 & $29.30 \pm 0.89$ & \\
\hline Isovaleric acid & 8.49 & $0.27 \pm 0.05$ & \\
\hline Hexanoic acid & 10.00 & $23.83 \pm 0.31$ & \\
\hline Heptanoic acid & 10.83 & $0.07 \pm 0.01$ & \\
\hline Octanoic acid & 11.58 & $4.56 \pm 0.17$ & \\
\hline Nonanoic acid & 12.26 & $0.04 \pm 0.01$ & \\
\hline Decanoic acid & 12.93 & $1.46 \pm 0.29$ & $*$ \\
\hline Total acids & & $67.20 \pm 2.09$ & \\
\hline Ethanol & 2.00 & $0.55 \pm 0.02$ & \\
\hline 2-Butanol & 2.47 & $0.85 \pm 0.07$ & \\
\hline 2-Pentanol & 3.18 & $0.79 \pm 0.12$ & \\
\hline 1-Butanol & 3.40 & $0.31 \pm 0.02$ & \\
\hline 1-Pentanol & 4.36 & $0.06 \pm 0.01$ & \\
\hline 2-Heptanol & 5.02 & $2.28 \pm 0.03$ & \\
\hline 1-Hexanol & 5.37 & $0.79 \pm 0.01$ & \\
\hline 2-Nonanol & 6.98 & $0.42 \pm 0.02$ & \\
\hline 1-Octanol & 7.36 & $0.15 \pm 0.02$ & \\
\hline 2,3-Butanediol & 7.64 & $0.15 \pm 0.03$ & $*$ \\
\hline Total alcohols & & $6.35 \pm 0.32$ & \\
\hline Hexane & 1.33 & $0.06 \pm 0.01$ & \\
\hline Cyclopentane & 1.36 & $0.02 \pm 0.01$ & * \\
\hline Isooctane & 1.39 & $0.02 \pm 0.01$ & $*$ \\
\hline Heptane & 1.41 & $0.04 \pm 0.01$ & $*$ \\
\hline Decane & 2.35 & $0.03 \pm 0.01$ & \\
\hline Total alkanes & & $0.12 \pm 0.03$ & \\
\hline$p$-Menth-2-ene & 3.08 & $1.23 \pm 0.10$ & \\
\hline$\alpha$-Myrcene & 3.53 & $0.05 \pm 0.01$ & \\
\hline$\alpha$-Phellandrene & 3.58 & $0.25 \pm 0.02$ & \\
\hline D-Limonene & 3.89 & $2.04 \pm 0.24$ & \\
\hline Total terpenoids & & $3.57 \pm 0.36$ & \\
\hline Ethyl acetate & 1.80 & $0.06 \pm 0.02$ & * \\
\hline Lactic acid methyl ester & 1.96 & $0.04 \pm 0.01$ & \\
\hline Ethyl butanoate & 2.56 & $0.22 \pm 0.04$ & * \\
\hline Butyl acetate & 2.81 & $0.35 \pm 0.17$ & * \\
\hline sec-Butyl butanoate & 3.26 & $0.15 \pm 0.03$ & \\
\hline Butyl propionate & 3.33 & $0.04 \pm 0.03$ & $*$ \\
\hline Amyl acetate & 3.64 & $0.04 \pm 0.01$ & \\
\hline Butyl butanoate & 4.06 & $0.42 \pm 0.05$ & \\
\hline Ethyl hexanoate & 4.20 & $1.13 \pm 0.07$ & \\
\hline Hexyl acetate & 4.58 & $1.00 \pm 0.15$ & \\
\hline Heptyl acetate & 5.58 & $0.04 \pm 0.01$ & \\
\hline Butyl hexanoate & 5.97 & $0.25 \pm 0.03$ & \\
\hline Ethyl octanoate & 6.18 & $0.22 \pm 0.01$ & \\
\hline Heptyl formate & 6.38 & $0.03 \pm 0.01$ & \\
\hline 2-Propylmalonic acid & 9.09 & $0.15 \pm 0.01$ & \\
\hline Total esters & & $4.13 \pm 0.60$ & \\
\hline Acetone & 1.61 & $0.03 \pm 0.01$ & \\
\hline 2-Heptanone & 3.75 & $4.36 \pm 0.90$ & * \\
\hline 2-Octanone & 4.72 & $0.17 \pm 0.01$ & \\
\hline Acetoin & 4.84 & $0.07 \pm 0.01$ & \\
\hline 5-Hepten-2-one, 6 methyl & 5.24 & $0.03 \pm 0.01$ & $*$ \\
\hline 2-Nonanone & 5.76 & $12.14 \pm 0.38$ & \\
\hline 8-Nonen-2-one & 6.30 & $0.35 \pm 0.01$ & \\
\hline 2-Undecanone & 7.77 & $0.26 \pm 0.02$ & \\
\hline Total ketones & & $17.41 \pm 1.33$ & \\
\hline Methane, isocyano- & 2.41 & $0.06 \pm 0.01$ & \\
\hline Toluene & 2.62 & $0.04 \pm 0.01$ & \\
\hline Valeraldehyde, 3-methyl & 2.89 & $0.04 \pm 0.02$ & * \\
\hline Styrene & 4.47 & $0.20 \pm 0.01$ & \\
\hline Caprolactone & 8.85 & $0.06 \pm 0.01$ & \\
\hline Dimethyl sulfone & 10.57 & $0.05 \pm 0.01$ & \\
\hline Total other & & $0.45 \pm 0.09$ & \\
\hline
\end{tabular}

*Different among producers at $P<0.05$. tyrosine, cysteine, and calcium phosphate (Tansman et al., 2015). In Parmigiano Reggiano, crystals are found after at least 12 mo of ripening (Nöel et al., 1996), whereas in our cheeses they were perceived already at 30 wk: this probably depends on the lower weight of the cheese mold (about $3 \mathrm{~kg}$ for Canestrato di Moliterno vs. about $40 \mathrm{~kg}$ for Parmigiano Reggiano). The variability we found for this sensory characteristic could be connected to the variations observed for moisture and $\mathrm{NaCl}$ (Dybing et al., 1988). The heterogeneity in the scores for "salty" and "moldy" were probably related to poorly standardized salting procedures and the proliferation of various molds on the surface of the cheeses. "Solubility" (tendency to dissolve in mouth) had the highest score in the sensory profile, consistent with the intense degradation of as1 casein observed, which is known to "soften" the cheese matrix. "Greasiness" and "adhesiveness" can be linked to the high fat content of the cheese. The main odor attributes were "sheepfold" and "buttery," whereas the taste was described mainly as "fermented," "pungent," and "bitter." The "buttery" perception was reported as a major attribute of Fiore Sardo, whereas "pungent" and "bitter" were among the descriptors of Canestrato Pugliese (Coda et al., 2006).

This study furnishes an initial characterization of Canestrato di Moliterno PGI that contributes to expanding the general information available for European Union protected cheeses. The main chemical and sensory traits of the cheese manufactured in spring indicated a certain uniqueness that is worth exploring by deepening our understanding of the role of the fondaco. Considering that European Union quality products are best marketed when suitable nutritional and organo-

Table 5. Sensory profile of 30-wk-old Canestrato di Moliterno cheese (scale from $0=$ absence of perception to $5=$ maximum intensity of perception)

\begin{tabular}{lcccc}
\hline Attribute & Modal value & Maximum & Minimum & Significance \\
\hline Solubility & 4 & 4 & 0 & \\
Hardness & 3 & 4 & 2 & \\
Adhesiveness & 3 & 4 & 0 & \\
Friability & 3 & 3 & 1 & \\
Greasiness & 3 & 3 & 1 & \\
Fermented & 3 & 5 & 0 & \\
Sheepfold & 2 & 3 & 1 & \\
Pungent & 2 & 3 & 1 & \\
Bitter & 2 & 3 & 0 & \\
Buttery & 2 & 3 & 0 & \\
Cheese rind & 1 & 2 & 1 & \\
Umami & 1 & 2 & 1 & \\
Smoky & 1 & 2 & 1 & $*$ \\
Salty & 4 & 5 & 1 & $*$ \\
Crystals & 1 & 3 & 0 & $*$ \\
Moldy & 1 & 2 & 0 & \\
Sour & 1 & 2 & 0 & $*$ \\
\hline
\end{tabular}

*Different among producers at $P<0.05$. 
leptic information are supplied, the results of the study could be used to improve marketing strategies and consumer demand.

\section{ACKNOWLEDGMENTS}

This work was financially supported by the project PSR Regione Basilicata "Razionalizzazione e innovazione della filiera del formaggio Canestrato di Moliterno IGP-RICaMo" (Basilicata Region, Potenza, Italy).

\section{REFERENCES}

Addis, M., A. Cabiddu, G. Pinna, M. Decandia, G. Piredda, A. Pirisi, and G. Molle. 2005a. Milk and cheese fatty acid composition in sheep fed Mediterranean forages with reference to conjugated linoleic acid cis-9,trans-11. J. Dairy Sci. 88:3443-3454.

Addis, M., G. Piredda, M. Pes, R. Di Salvo, M. F. Scintu, and A. Pirisi. 2005b. Effect of the use of three different lamb paste rennet on lipolysis of the PDO Pecorino Romano cheese. Int. Dairy J. 15:563-569.

AFNOR. 1994. Controle de la qualitè des produits alimentaires-analyse sensorielle, 5e ed. AFNOR, Paris, France.

Andrews, A. T. 1983. Proteinases in normal bovine milk and their action on caseins. J. Dairy Res. 50:45-55.

Castro, T., T. Manso, V. Jimeno, M. Del Alamo, and A. R. Mantecón. 2009. Effects of dietary sources of vegetable fats on performance of dairy ewes and conjugated linoleic acid (CLA) in milk. Small Rumin. Res. 84:47-53.

Cevoli, C., L. Cerretani, A. Gori, M. F. Caboni, T. Gallina Toschi, and A. Fabbri. 2011. Classification of Pecorino cheeses using electronic nose combined with artificial neural network and comparison with GC-MS analysis of volatile compounds. Food Chem. 129:13151319.

Coda, R., E. Brechany, M. De Angelis, S. De Candia, R. Di Cagno, and M. Gobbetti. 2006. Comparison of the compositional, microbiological, biochemical and volatile profile characteristics of nine Italian ewe's milk cheeses. J. Dairy Sci. 89:4126-4143.

Collins, Y. F., P. L. H. McSweeney, and M. G. Wilkinson. 2003. Lipolysis and free fatty acid catabolism in cheese: A review of current knowledge. Int. Dairy J. 13:841-866.

Di Cagno, R., J. Banks, L. Sheean, P. F. Fox, E. Y. Brechany, A. Corsetti, and M. Gobbetti. 2003. Comparison of the microbiological, compositional, biochemical, volatile profile and sensory characteristics of three Italian PDO ewe's milk cheeses. Int. Dairy J. 13:961-972.

Dybing, S. T., J. A. Wiegand, S. A. Brudvig, E. A. Huang, and R. C. Chandan. 1988. Effect of processing variables on the formation of calcium lactate crystals on Cheddar cheese. J. Dairy Sci. $71: 1701-1710$

European Union. 2010. Regolamento $N^{\circ} 441 / 2010$ della commissione del 21 maggio 2010 recante iscrizione di una denominazione nel registro delle denominazioni d'origine protette e delle indicazioni geografiche protette [Canestrato di Moliterno (IGP)]. Off. J L126/6, 22 May 2010.

Faccia, M., A. Trani, G. Gambacorta, P. Loizzo, A. Cassone, and F. Caponio. 2015. Production technology and characterization of Fiordilatte cheese from ovine and caprine milk. J. Dairy Sci. 98:1402-1410

Felicio, T. L., E. A. Esmerino, V. A. S. Vidal, L. P. Cappato, R. K. A. Garcia, R. N. Cavalcanti, M. Q. Freitas, C. A. Conte Júnior, M. C. Padilha, M. C. Silva, R. S. L. Raices, D. B. Arellano, H. M. A. Bollini, M. A. R. Pollonio, and A. G. Cruz. 2016. Physico-chemical changes during storage and sensory acceptance of low sodium probiotic Minas cheese added with arginine. Food Chem. 196:628-637.

Fernández-García, E., M. Carbonell, and M. Nunez. 2002. Volatile fraction and sensory characteristics of Manchego cheese. 1. Comparison or raw and pasteurized milk cheese. J. Dairy Res. 69:579593.

Gaze, L. V., B. R. Oliveira, L. L. Ferrao, D. Granato, R. N. Cavalcanti, C. A. Conte Júnior, A. G. Cruz, and M. Q. Freitas. 2015. Preference mapping of dulce de leche commercialized in Brazilian markets. J. Dairy Sci. 98:1443-1454.

IDF (International Dairy Federation). 1986. Cheese and processed cheese products. Determination of dry matter. IDF Standard No. 4. FIL-IDF, Brussels, Belgium.

IDF (International Dairy Federation). 1988. Cheese and cheese products- Determination of chloride content. IDF Standard No. 88A FIL-IDF, Brussels, Belgium.

IDF (International Dairy Federation). 1989. Determination of pH. IDF Standard No 115A. FIL-IDF, Brussels, Belgium.

ISO. 1993. ISO 8586-1. Sensory analysis: General guidance for the selection, training and monitoring of assessors. Part 1: Selected assessors. International Organization for Standardization (ISO), Geneva, Switzerland.

Istituto Nazionale di Sociologia Rurale. 1990. Atlante dei prodotti tipici: i formaggi. Franco Angeli Libri, Milan, Italy.

Lencioni, L., M. Bertuccioli, and F. Galgano. 1988. Extraction method for free fatty acid determination in cheese. Indust. Alim. 37:171175 .

Nöel, Y., M. Zannoni, and E. A. Hunter. 1996. Texture of Parmigiano Reggiano cheese: Statistical relationship between rheological and sensory variates. Lait 76:243-254.

Nudda, A., M. A. McGuire, G. Battacone, and G. Pulina. 2005. Seasonal variation in conjugated linoleic acid and vaccenic acid in milk fat of sheep and its transfer to cheese and ricotta. J. Dairy Sci. 88:1311-1319.

Pinarelli, C. 2006. Il Canestrato di Moliterno Stagionato in Fondaco. Il Latte 31:86.

Pirisi, A., R. Comunian, P. P. Urgeghe, and M. F. Scintu. 2011. Sheep's and goat's dairy products in Italy: Technological, chemical, microbiological, and sensory aspects. Small Rumin. Res. 101:102-112.

Pirisi, A., G. Pinna, M. Addis, G. Piredda, R. Mauriello, S. De Pascale, S. Caira, G. Mamone, P. Ferranti, F. Addeo, and L. Chianese. 2007. Relationship between the enzymatic composition of lamb rennet paste and proteolytic, lipolytic pattern and texture of PDO Fiore Sardo ovine cheese. Int. Dairy J. 17:143-156.

Qian, M. C., and H. M. Burbank. 2007. Hard Italian cheeses: Parmigiano Reggiano and Grana Padano. Pages 421-439 in Improving the Flavor of Cheese. B. C. Weimer, ed. Woodhead Publishing Ltd., Cambridge, UK.

Rubino, R., M. Pizzillo, G. Morone, M. V. Schettino, M. A. Di Napoli, and S. Claps. 2009. Stabilità delle produzioni casearie ovine lucane e strumenti per una diagnosi veloce. Sci. Tecn. Latt. Cas. 60:149-153.

Santoro, M., and M. Faccia. 1998. Influence of mold size and rennet on proteolysis and composition of Canestrato Pugliese cheese. Ital. J. Food Sci. 3:217-228.

Scintu, M. F., A. Del Caro, P. P. Urgeghe, C. Piga, and R. Di Savo. 2010. Sensory profile development for an Italian PDO ewe's milk cheese at 2 different ripening times. J. Sens. Stud. 25:577-590.

Tansman, G. F., P. S. Kindstedt, and J. M. Hughes. 2015. Crystal fingerprinting: Elucidating the crystals of Cheddar, ParmigianoReggiano, Gouda, and soft washed-rind cheeses using powder x-ray diffractometry. Dairy Sci. Technol. 95:651-664.

Tofalo, R., M. Schirone, G. Fasoli, G. Perpetuini, F. Patrignani, A. C. Manetta, R. Lanciotti, A. Corsetti, G. Martino, and G. Suzzi. 2015. Influence of pig rennet on proteolysis, organic acids content and microbiota of Pecorino di Farindola, a traditional Italian ewe's raw milk cheese. Food Chem. 175:121-127. 